\title{
Genetic diversity of the forage peanut in the Jequitinhonha, São Francisco, and Paranã River valleys of Brazil
}

\author{
H.S.F.S. Azêvedo ${ }^{1}$, A.C.B. Sousa ${ }^{2}$, K. Martins ${ }^{3}$, J.C. Oliveira ${ }^{4}$, R.B.T. Yomura ${ }^{5}$, \\ L.M. Silva ${ }^{5}$, J.F.M. Valls ${ }^{6}$, G.M.L. Assis ${ }^{5}$ and T. Campos ${ }^{5}$ \\ ${ }^{1}$ Programa de Pós-Graduação em Biotecnologia e Recursos Genéticos da \\ Rede Bionorte, Embrapa Rondônia, Porto Velho, RO, Brasil \\ ${ }^{2}$ Universidade Federal da Paraíba, João Pessoa, PB, Brasil \\ ${ }^{3}$ Universidade Federal de São Carlos, Sorocaba, SP, Brasil \\ ${ }^{4}$ Universidade Federal do Acre, Rio Branco, AC, Brasil \\ ${ }^{5}$ Embrapa Acre, Rio Branco, AC, Brasil \\ ${ }^{6}$ Embrapa Recursos Genéticos e Biotecnologia, Parque Estação Biológica, \\ Brasília, DF, Brasil
}

Corresponding author: T. Campos

E-mail: tatiana.campos@embrapa.br

Genet. Mol. Res. 15 (3): gmr.15038601

Received March 7, 2016

Accepted April 25, 2016

Published September 9, 2016

DOI http://dx.doi.org/10.4238/gmr.15038601

Copyright $(\mathcal{C} 2016$ The Authors. This is an open-access article distributed under the terms of the Creative Commons Attribution ShareAlike (CC BY-SA) 4.0 License

ABSTRACT. Arachis pintoi and A. repens are legumes with a high forage value that are used to feed ruminants in consortium systems. Not only do they increase the persistence and quality of pastures, they are also used for ornamental and green cover. The objective of this study was to analyze microsatellite markers in order to access the genetic diversity of 65 forage peanut germplasm accessions in the section Caulorrhizae of the genus Arachis in the Jequitinhonha, São Francisco and Paranã River valleys of Brazil. Fifty-seven accessions of $A$. pinto $i$ 
and eight of $A$. repens were analyzed using 17 microsatellites, and the observed heterozygosity $\left(H_{\mathrm{O}}\right)$, expected heterozygosity $\left(H_{\mathrm{E}}\right)$, number of alleles per locus, discriminatory power, and polymorphism information content were all estimated. Ten loci (58.8\%) were polymorphic, and 125 alleles were found in total. The $H_{\mathrm{E}}$ ranged from 0.30 to 0.94 , and $H_{\mathrm{O}}$ values ranged from 0.03 to 0.88 . By using Bayesian analysis, the accessions were genetically differentiated into three gene pools. Neither the unweighted pair group method with arithmetic mean nor a neighbor-joining analysis clustered samples into species, origin, or collection area. These results reveal a very weak genetic structure that does not form defined clusters, and that there is a high degree of similarity between the two species.

Key words: Arachis pintoi; Arachis repens; Forage legume; Molecular marker; SSR

\section{INTRODUCTION}

Brazilian livestock production in domestic and international markets has increased in recent years because of a favorable economic environment and market (Valentim and Andrade, 2009; Claudino et al., 2013). According to the Brazilian Ministry of Agriculture, Livestock, and Food Supply (2015), meat production will supply $44.5 \%$ of the world market's demand until 2020. However, vigor, pasture quality, and impacts on the environment are some of the factors that limit further increases in productivity.

Among the alternatives to recover degraded pastures and to ensure the sustainability of the soil, grasses intercropped with forage legumes is an important option. In 2013, legume cultivars (Stylosanthes spp 'Campo Grande' and Arachis pintoi 'Belomonte') occupied two million hectares and generated R\$267 million for Brazilian cattle breeders (Valentim and Andrade, 2015).

The advantages of pasture diversification by introducing forage legumes in traditional production systems include a large dry matter yield, high nutritional value, and good biological nitrogen fixation in the soil, which reduce costs for farmers, increase the production of meat and milk, and prevent the opening up of new areas of forest (Carvalho and Pires, 2008; Azevedo et al., 2014).

The forage peanut species A. pintoi Krapov. \& W.C. Greg. and Arachis repens Handro of the taxonomic section Caulorrhizae Krapov. \& W.C. Greg. have several characteristics related to persistence under grazing and are a food source for animals in the crop-livestock system (Valentim and Andrade, 2015). A. repens has potential for forage use; however, it is most commonly used as an ornamental plant due to its good ground cover and fast growth (Azevedo et al., 2011).

The geographical distribution of section Caulorrhizae comprises the basins of the rivers Jequitinhonha, São Francisco, and Paranã, which reaches the Atlantic coast and covers parts of the Brazilian states of Goiás, Bahia, and Minas Gerais. Previous research has suggested that the greatest genetic variability in accessions of this section is concentrated in the São Francisco River basin (Gimenes et al., 2000).

Discrimination between original accessions of $A$. pintoi and $A$. repens is based on morphological characteristics, such as leaflet shape and size and bristle density and location (Krapovickas and Gregory, 1994; Monçato, 1995; Menezes et al., 2012). However, with the increase in the number of accessions obtained from germplasm collection expeditions in the

Genetics and Molecular Research 15 (3): gmr.15038601 
last 20 years, types with intermediate characteristics have been found (Monçato, 1995).

Despite the importance of morphological characteristics in the analysis of diversity, they also have limitations. In plants with a narrow genetic basis, they may not be sufficient for the clear-cut distinction of different genotypes. There is no consensus on the separation of $A$. pintoi and $A$. repens based on molecular studies. Gimenes et al. (2000) reported high similarity between accessions of $A$. pintoi and A. repens, whereas Palmieri et al. (2010) did not find any groups that corresponded to the separation of the two species.

Microsatellite markers (simple sequence repeats, SSRs) have been successfully used in characterizing plant diversity (Jones et al., 2009), and have detected high variability among the accessions of section Caulorrhizae (Palmieri et al., 2002; Gimenes et al., 2007). Microsatellite loci exhibit high indices of polymorphism and transferability within the genus Arachis, allowing their use in inter- and intraspecific genetic studies (Palmieri et al., 2002; Moretzsohn et al., 2005; Bravo et al., 2006; Gimenes et al., 2007; Angelici et al., 2008).

$A$. pintoi and A. repens are important genetic resources with potential economic value for agricultural use (Valls, 2005). Therefore, the conservation and use of, and access to, genetic variability are crucial in forage peanut breeding programs (Assis and Valentim, 2009). The objective of this study was to analyze the genetic diversity of 65 accessions of section Caulorrhizae collected in the valleys of the Jequitinhonha, São Francisco, and Paranã rivers using microsatellite markers.

\section{MATERIAL AND METHODS}

\section{Plant material}

We evaluated 57 accessions of $A$. pintoi and eight of $A$. repens obtained from the Active Germplasm Bank of Forage Peanut, Embrapa Acre, Brazil (Table 1). Accession collection started in the early 1980s, and covered the natural geographical distribution of the species along the Jequitinhonha, São Francisco, and Paranã rivers in Brazil (Figure 1).

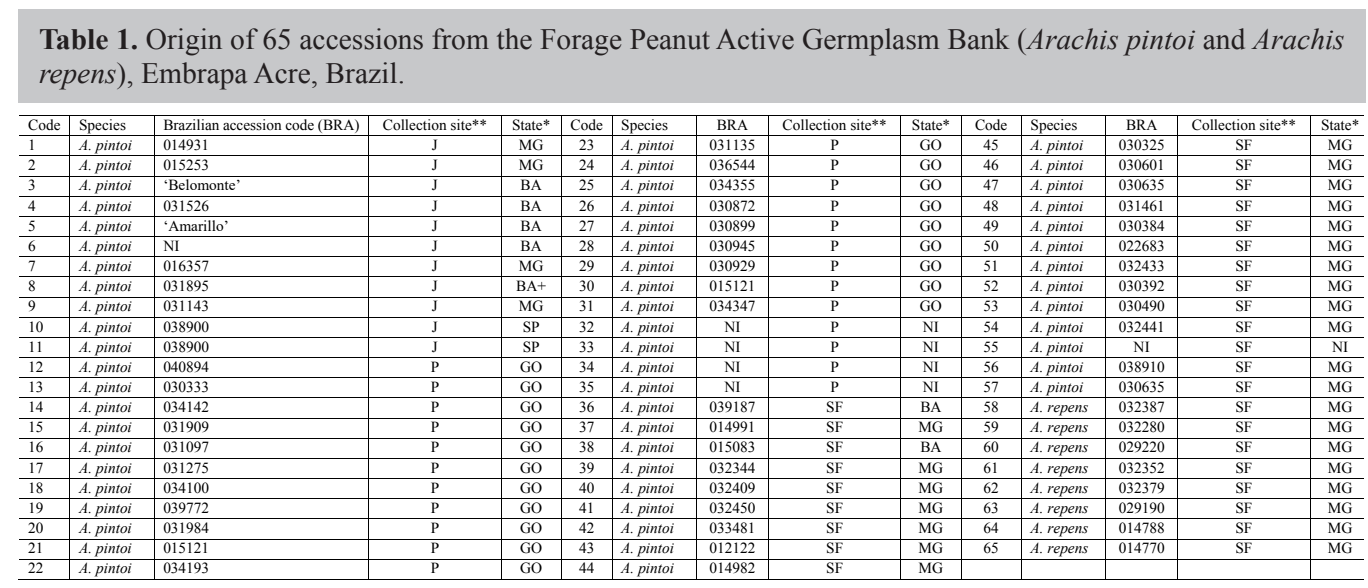

NI, no information. *Brazilian states: BA, Bahia; MG, Minas Gerais; GO, Goiás. + [BRA-031895: autotriploid accession $(2 \mathrm{n}=30)$ naturally appearing in GK 12787 field plot at San José, Costa Rica, and identified as distinct by Pedro Argel/CIAT]. **Collection sites: J, Jequitinhonha; P, Paranã; SF, São Francisco. 


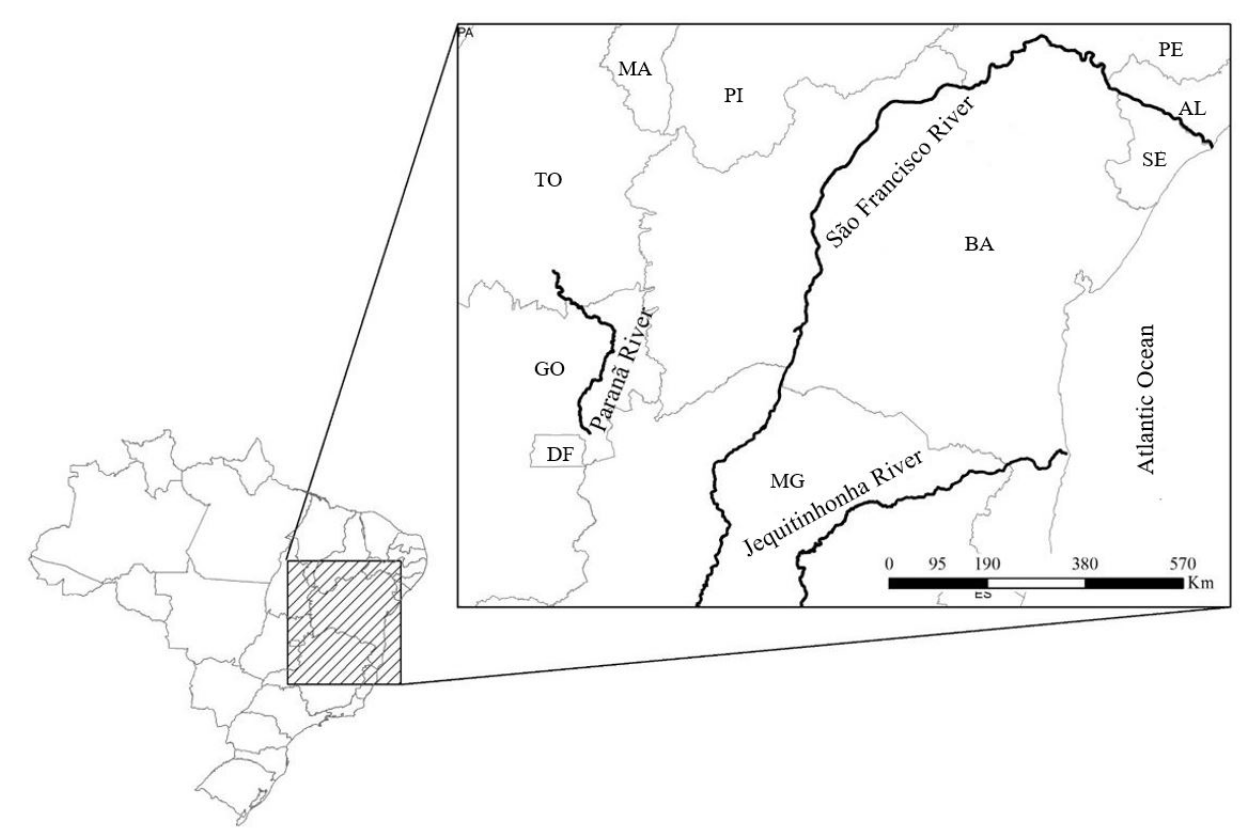

Figure 1. Geographical locations of the Jequitinhonha, São Francisco, and Paranã River valleys in Brazil.

\section{DNA extraction and microsatellite loci}

Molecular analyses were performed in the Morphogenesis and Molecular Biology Laboratory (LabMol) at Embrapa Acre. Total genomic DNA was extracted from fresh young leaves using the protocol described by Hoisington et al. (1994), and was diluted and quantified by comparison with standard DNA using agarose gel electrophoresis (1\%).

Seventeen SSR markers that are described in the literature were tested and optimized for the annealing temperature. Of these, four loci were developed based on specific sequences for A. hypogaea L. (Ah) (Gimenes et al., 2007), 10 were developed for A. pintoi (Ap) (Palmieri et al., 2002), and three were developed for Arachis glabrata Benth. (Ag) (Hoshino et al., 2006). A. hypogaea and A. glabrata belong to the sections Arachis and Rhizomatosae Krapov. \& W.C. Greg., respectively.

\section{Statistical analysis}

The following genetic diversity parameters were estimated: the observed heterozygosity $\left(H_{\mathrm{O}}\right)$, expected heterozygosity $\left(H_{\mathrm{E}}\right)$, number of alleles $(N)$ per locus, and the polymorphism information content (PIC) using the Tools For Population Genetic Analyses (TFPGA) software (http://www.marksgeneticsoftware.net/tfpga.htm). The PIC was calculated according to the equation of Botstein et al. (1980):

$$
\text { Pic }=1-\sum_{i=1}^{n} f_{i}^{2}-\sum_{i=1}^{n-1} \sum_{j=i+1}^{n} 2 f i^{2} f j^{2}
$$

Genetics and Molecular Research 15 (3): gmr.15038601 
where $f_{i}$ is the frequency of the $i^{\text {th }}$ allele and $f_{j}$ is the frequency of the $j^{\text {th }}$ allele, summing over alleles.

To compare the efficiency of the markers to identify varieties, the power of discrimination $(D)$ was estimated for each site based on the following equation described by Tessier et al. (1999):

$$
D_{k}=1-\sum_{j-1}^{l} p_{j} \frac{N p_{j}-1}{N-1}
$$

Genetic distances among the accessions were calculated using the modified Roger's distance method in TFPGA, and a dendrogram was constructed using the unweighted pair group method with arithmetic mean (UPGMA) clustering criterion in NTSYSpc (http://www. exetersoftware.com/cat/ntsyspc/ntsyspc.html).

Clustering consistency was tested by resampling using 10,000 bootstraps in the program BOOD (Coelho, 2002). The consistency of the dendrogram was evaluated by a cophenetic correlation between the distances represented by the original dendrogram and the genetic distances between pairs of accessions. The significance of this correlation was tested using the Mantel test with 10,000 random permutations. The cophenetic correlation and its significance were calculated using NTSYSpc.

The Bayesian method implemented in the STRUCTURE software was used to investigate the genetic organization of the accessions. This analysis considers the separation of the total number of individuals analyzed in clusters, giving them a $\mathrm{K}$ value that represents the number of different gene pools, assuming Hardy-Weinberg equilibrium and a lack of linkage disequilibrium among the loci. Consequently, clusters of individuals sharing the same gene pool are inferred, with no need for prior information on its origin.

Analysis was performed on all of the accessions, and $\mathrm{K}$ ranged from 1 to 12 . Five independent simulations were conducted for each $\mathrm{K}$ using the admixture model, independent allele frequencies, a burn-in of 10,000, and 10,000 Markov chain Monte Carlo iterations. The most probable $\mathrm{K}$ number was determined with delta $\mathrm{K}$ values according to Evanno et al. (2005) using STRUCTURE HARVESTER (Earl and vonHoldt, 2012). The accessions were allocated to clusters according to the probability of each individual belonging to each cluster. Cluster analysis was performed using the neighbor-joining (NJ) method in DARwin (http:// darwin.cirad.fr/) using the same matrix as Roger's modified distance that was obtained from TFPGA.

\section{RESULTS AND DISCUSSION}

Seventeen microsatellite markers were tested. Only 10 loci (58.8\%; Table 2) were polymorphic and produced definite bands for genotyping. The other loci were monomorphic or nonspecific (41.2\%; Ap33, Ah2, Ah26, Ah30, Ap40, Ah51, and Ah126). A total of 125 alleles were found, with fragments ranging from $97 \mathrm{bp}$ (Ah7) to $322 \mathrm{bp}$ (Ap152) in length. $N$ varied from four (Ap175) to 23 (Ap175), with an average of 12.5 alleles per locus. Palmieri et al. (2010) used 26 microsatellite markers and found 20 polymorphic loci, detecting a total of 196 alleles in 33 accessions of $A$. pinto $i$ and 10 of $A$. repens with an average of 9.8 alleles per locus, a smaller number than reported here.

Genetics and Molecular Research 15 (3): gmr.15038601 
Table 2. Characterization of loci and annealing temperature (AT), allele length (bp), number of alleles per locus $(N)$, expected heterozygosity $\left(H_{\mathrm{E}}\right)$, observed heterozygosity $\left(H_{\mathrm{o}}\right)$, polymorphism information content (PIC), and discriminatory power $(D)$ for 65 accessions of forage peanuts (Arachis pintoi and Arachis repens) from the Active Germplasm Bank in Embrapa Acre, Brazil.

\begin{tabular}{l|c|c|c|c|c|c|c}
\hline Locus & $\mathrm{AT}\left({ }^{\circ} \mathrm{C}\right)$ & Allele length (bp) & $N$ & $H_{\mathrm{E}}$ & $H_{\mathrm{O}}$ & PIC & $D$ \\
\hline $\mathrm{Ap} 152^{*}$ & 58.5 & $259-322$ & 11 & 0.88 & 0.30 & 0.88 & 0.98 \\
\hline $\mathrm{Ap} 175^{*}$ & 55.4 & $174-230$ & 23 & 0.89 & 0.46 & 0.88 & 0.98 \\
\hline $\mathrm{Ap} 176^{*}$ & 50.0 & $194-246$ & 15 & 0.89 & 0.30 & 0.89 & 0.97 \\
\hline $\mathrm{Ag} 39^{* *}$ & 52.1 & $150-190$ & 22 & 0.94 & 0.23 & 0.93 & 0.99 \\
\hline $\mathrm{Ag} 140^{* *}$ & 57.3 & $164-191$ & 4 & 0.39 & 0.03 & 0.38 & 0.73 \\
\hline $\mathrm{Ag} 171^{* *}$ & 48.2 & $164-196$ & 4 & 0.32 & 0.06 & 0.31 & 0.72 \\
\hline $\mathrm{Ah} 6-125^{* * *}$ & 48.2 & $170-194$ & 11 & 0.30 & 0.26 & 0.30 & 0.77 \\
\hline $\mathrm{Ah} 7^{* * *}$ & 52.1 & $97-122$ & 11 & 0.85 & 0.26 & 0.84 & 0.92 \\
\hline $\mathrm{Ah} 21^{* * *}$ & 57.3 & $100-135$ & 13 & 0.76 & 0.21 & 0.75 & 0.96 \\
\hline $\mathrm{Ah} 282^{* * *}$ & 55.4 & $173-202$ & 11 & 0.75 & 0.88 & 0.74 & 0.91 \\
\hline Total & & & 125 & & & & \\
\hline Mean & & & 12.5 & 0.70 & 0.30 & 0.69 & 0.89 \\
\hline
\end{tabular}

*Palmieri et al. (2002); **Hoshino et al. (2006); ***Gimenes et al. (2007). Specific sequences for Arachis pinto (Ap), A. glabrata (Ag), and A. hypogaea (Ah).

PIC values ranged from 0.30 to 0.93 , with a mean value of 0.69 (Table 2). Of the 10 loci analyzed, seven had PIC values greater than 0.5 , which is considered highly informative for genetic diversity studies (Botstein et al., 1980).

Microsatellites are present both in coding and non-coding regions, and can be found in nuclear and organellar genomes (Kalia et al., 2011). The Ap176 locus was highly informative $(\mathrm{PIC}=0.89)$, and had $92 \%$ identity and $90 \%$ similarity to an mRNA sequence (GW937987.1) isolated from a cDNA library of roots of Arachis duranensis Krapov. \& W.C. Greg. Palmieri et al. (2010) found that the locus Ap176 is similar to a lipoxygenase enzyme (41\% identity and $47 \%$ similarity). Therefore, the locus is closely related to the expression of a gene and can be classified as a functional marker.

Among the polymorphic loci found, locus Ag39 had the highest PIC value (0.93). The sequence from which this marker was derived originated from A. glabrata, and had $100 \%$ similarity and 94\% identity with a sequence from A. hypogaea (DQ099178.1).

The conservation of microsatellite sites among species and even among genera makes it possible to use the same markers in related species. This characteristic of transferability is limited by the homology of DNA sequences between related species. It was found in the present study that regardless of the species (A. hypogaea, A. glabrata, or A. pintoi) from which the locus was developed, all of the loci used were successfully amplified in both species.

The $D$ values ranged from 0.73 to 0.99 , with a mean of 0.89 (Table 2). $D$ values for all of the loci were high, demonstrating the high discriminatory power of these loci and their potential in fingerprinting studies.

The $H_{\mathrm{E}}$ was high for most loci, and varied from 0.30 to 0.94 , with a mean of 0.70 . The $H_{\mathrm{O}}$ values ranged from 0.03 to 0.88 , with a mean value of 0.30 . The low value obtained for the average $H_{\mathrm{O}}$ was expected, because species in the Arachis genus are autogamous (Krapovickas and Gregory, 1994). Similar results were obtained in another study with species of the genus Arachis (Hoshino et al., 2006), confirming the reproductive system of the species studied.

Only locus Ah282 had an observed heterozygosity value that was higher than expected, indicating that plants often have heterozygotic regions and do not solely exhibit autogamous homozygosis. This may have been a result of crossings between different accessions in the natural habitat before collection, where heterozygosity was maintained due to vegetative

Genetics and Molecular Research 15 (3): gmr.15038601 
propagation in the conservation of accessions. This genomic trait supports the classification of the reproductive system of $A$. pintoi as mixed, in which a cross-fertilization rate of $36.7 \%$ has been detected (Oliveira, 2015). Values of $H_{\mathrm{O}}$ higher than expected have also been obtained in genetic diversity studies in section Caulorrhizae (Palmieri et al., 2010).

A total of 65 private alleles distributed between the two species were found. Thirteen alleles $(20.3 \%)$ were exclusive to $A$. pintoi, two (3.1\%) were only found in accessions of $A$. repens, and the majority (50 alleles, 78.1\%) was shared between the two species; A. repens and A. pintoi have a very close genetic relationship. Palmieri et al. (2010) obtained 99 (49\%) private alleles in A. pintoi, 21 (10.7\%) exclusive to A. repens and 79 (40.3\%) shared between the two species. It is noteworthy that these authors analyzed different microsatellite loci that were developed from specific sequences of $A$. pintoi. As in the present study, seven loci were used for other species, and the alleles detected were highly conserved between $A$. pinto $i$ and $A$. repens.

The Bayesian analysis revealed that the largest delta $\mathrm{K}$ value was for $\mathrm{K}=3$ (Figures 2 and 3), indicating the existence of three distinct gene pools.

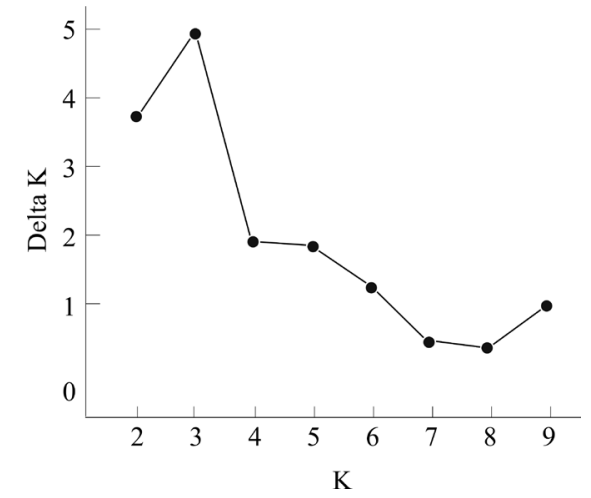

Figure 2. Delta graph $(\mathrm{K})$ with $\mathrm{K}=3$, obtained from STRUCTURE analysis using the model from Evanno et al. (2005) in 65 forage peanut accessions collected in the valleys of the São Francisco, Paranã, and Jequitinhonha rivers, belonging to the Active Germplasm Bank of Embrapa Acre, Brazil.

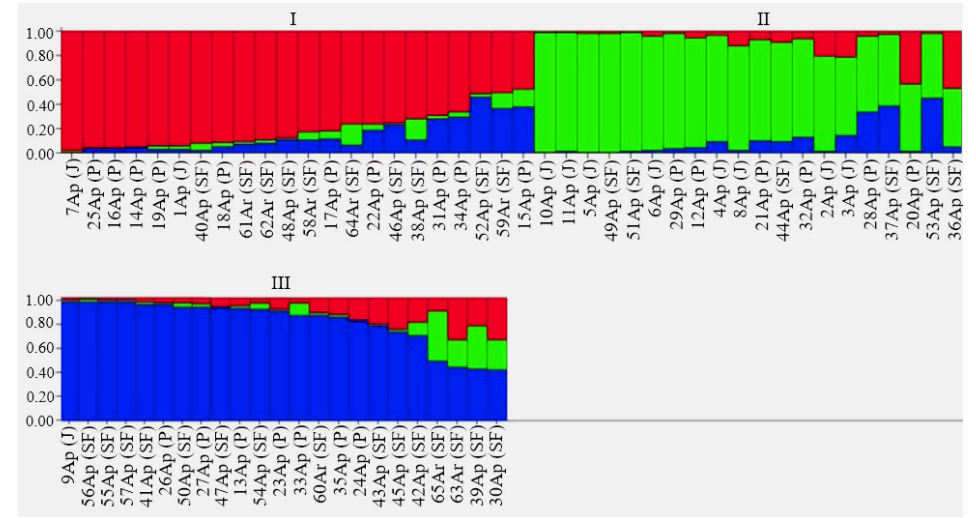

Figure 3. Analysis of gene pools in 65 accessions of forage peanut according to a Bayesian analysis using STRUCTURE. Each individual is represented by a column. The evaluated accessions were divided into three gene pools $(\mathrm{K}=3)$ : red, gene pool I; green, gene pool II; blue, gene pool III.

Genetics and Molecular Research 15 (3): gmr.15038601 
Gene pool I contained 22 accessions, 17 accessions of $A$. pintoi and 5 of $A$. repens. Ten accessions (41.7\%) collected from the Paranã valley, 10 (33.3\%) from the São Francisco River valley, and two (18.2\%) from the Jequitinhonha valley were grouped into gene pool I.

Gene pool II included 20 accessions, all of which were accessions of $A$. pintoi. In this pool, six (25.0\%) accessions were from the Paranã valley, six (20.0\%) from the São Francisco valley, and eight (72.3\%) from the Jequitinhonha valley. Gene pool III included 23 accessions, 20 accessions of $A$. pintoi and three of $A$. repens. In this gene pool, seven (29.2\%) accessions were from the valley of the Paranã River, $15(50.0 \%)$ were from the São Francisco valley, and one $(9.1 \%)$ was from the Jequitinhonha valley.

According to these results, no clustering pattern was found that supported the separation of $A$. pintoi and $A$. repens, or the geographical subdivision of the area of occurrence over the valleys. However, although there was a formation of groups with both species, most (62.5\%) of the A. repens accessions were gathered in one gene pool (I). The other A. repens accessions were grouped in gene pool III. Accession 60Ar exhibited a high degree of ancestry from gene pool III. This result corroborates those obtained in studies by Gimenes et al. (2000) and Menezes et al. (2012), who found that accession 60Ar was grouped with A. pintoi accessions, confirming the proximity of this $A$. repens accession to A. pintoi.

Molecular phylogeny has confirmed the monophyletic nature of $A$. pintoi and $A$. repens accessions of the section Caulorrhizae (Friend et al., 2010). Therefore, the accessions should have very similar genomes, because they share a recent common ancestor and the same original gene pool. In addition, the existence of fertile interspecific hybrids between the two species has not been proven (Pucciariello et al., 2013).

The dendrogram obtained by the UPGMA (Figure 4) and NJ analyses (Figure 5) revealed that there was no clustering of accessions according to their naturally occurring sites or species designations, showing a lack of genetic structure that allows the formation of defined groups. The cophenetic correlation coefficient between the dendrogram and genetic distance matrix was high $(r=0.80)$, demonstrating that the dendrogram revealed consistency in the genetic relationship expressed by the distances obtained from the dataset.

Despite the lack of structure in the formation of the clusters, the extreme values of genetic distance found were consistent with the distances between the collection sites. The shortest genetic distance (0.22) was observed between two accessions of A. repens (Ar62 and Ar61) collected in the valley of the São Francisco River. The greatest genetic distance (0.94) was observed between Ap27 and Ap10, two A. pintoi accessions that originated in the valleys of the Paranã and Jequitinhonha rivers, respectively.

The similarity between $A$. pintoi and $A$. repens accessions and the lack of a clustering pattern based on species assignment have already been observed in morphological, agronomic, bromatological, and molecular characterization studies. Assis et al. (2009) characterized the bristle of the stigmatic surface and found four clusters, three of which clustered accessions of both species. Menezes et al. (2012) studied the agronomic and bromatological characterization of the section Caulorrhizae and found six clusters, four of which consisted of $A$. pintoi and $A$. repens genotypes.

The taxonomic classification of $A$. pintoi and A. repens by Krapovickas and Gregory (1994) was based on the only two accessions known before the 1980s, which were GKP 10538 (A. repens) and GK 12787 (A. pintoi). These accessions have divergent and contrasting morphological characteristics.

However, as the number of collected accessions increases, it is possible to see the

Genetics and Molecular Research 15 (3): gmr.15038601 


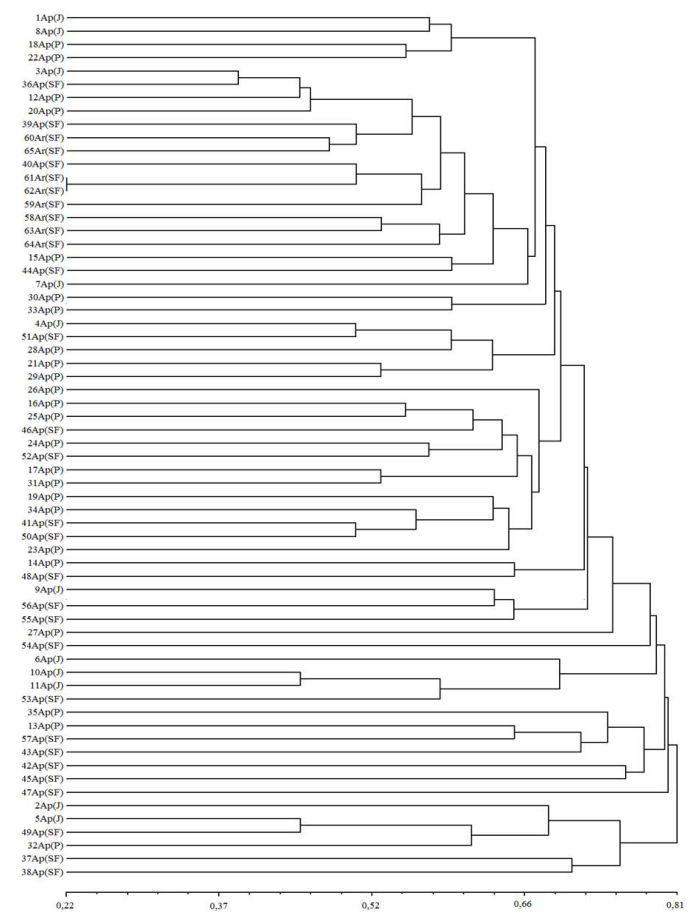

Figure 4. Dendrogram of 65 forage peanut accessions constructed using the unweighted pair group method with arithmetic mean with Roger's modified distance and 10 microsatellite loci.

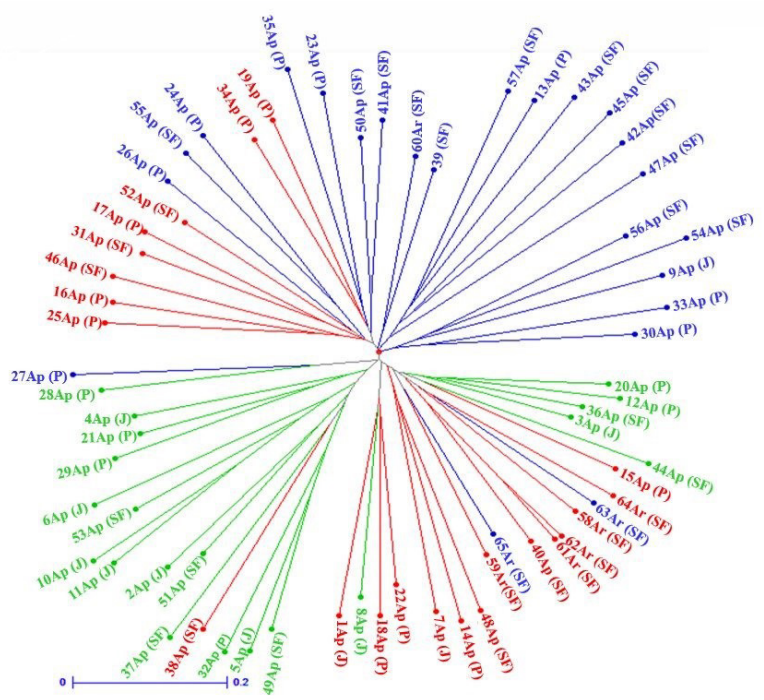

Figure 5. Neighbor-joining tree representing the genetic relationships among 65 accessions of forage peanut. Dots follow clustering formation generated by the STRUCTURE software with $\mathrm{K}=3$ : red, gene pool I; green, gene pool II; blue, gene pool III.

Genetics and Molecular Research 15 (3): gmr.15038601 
appearance of materials with intermediate morphological characteristics among the original classification used by the above-mentioned authors. As reported by Monçato (1995), there are accessions with intermediate characters between $A$. pintoi and $A$. repens that may have appeared by natural hybridization. As described above, $78.1 \%$ of private alleles were shared between the species. Despite the similarity between A. pintoi and A. repens and the use of markers with high discriminatory power, no duplicates were found in the accessions analyzed. Therefore, the samples in the Active Germplasm Bank have been diversified. The close proximity between $A$. pintoi and $A$. repens has been demonstrated once more and highlights the complexity among related species. Knowledge of genetic diversity and the correct identification of forage peanut accessions are also important for proper conservation planning and the use of crosses in breeding programs.

\section{Conflicts of interest}

The authors declare no conflict of interest.

\section{ACKNOWLEDGMENTS}

The authors would like to thank Unipasto and FUNTAC (TO: \#008/2012) for financial support, and Coordenação de Aperfeiçoamento de Pessoal de Nível Superior (CAPES) for granting Master's program scholarships. In addition, we would like to thank Bruno de Andrade Imbroisi and Rui Peruquetti for help in drawing the figures.

\section{REFERENCES}

Angelici CMLCD, Hoshino AA, Nóbile PM, Palmieri DA, et al. (2008). Genetic diversity in section Rhizomatosae of the genus Arachis (Fabaceae) based on microsatellite markers. Genet. Mol. Biol. 31: 79-88. http://dx.doi.org/10.1590/ $\underline{\text { S1415-47572008000100016 }}$

Assis GML and Valentim JF (2009). Programa de melhoramento genético do amendoim forrageiro: avaliação agronômica de acessos no Acre. Amazônia: Ci. \& Desenv. 4: 207-215.

Assis GML, Valentim JF, Carneiro Junior JM, Silva HSF, et al. (2009). Caracterização da pilosidade da superfície estigmática de genótipos de amendoim forrageiro. In: Anais do $46^{\circ}$ Reunião Anual da Sociedade Brasileira de Zootecnia, Maringá.

Azevedo JMA, Silva HSF, Assis GML, Santos LFA, et al. (2011). Genetic divergence among accessions of Arachis repens based on vegetative morphological traits. R. Bras. Zootec. 40: 2067-2073. http://dx.doi.org/10.1590/S1516$\underline{35982011001000001}$

Azevedo JMA, Assis GML, Saggin Junior OJ and Silva HSF (2014). Riqueza e frequência de espécies de fungos micorrízicos arbusculares em genótipos de amendoim forrageiro no Acre, Norte do Brasil. Acta Amaz. 44: 157-168. http://dx.doi.org/10.1590/S0044-59672014000200001

Botstein D, White RL, Skolnick M and Davis RW (1980). Construction of a genetic map in man using restriction fragment length polymorphism. Am. J. Hum. Genet. 32: 314-331.

Bravo JP, Hoshino AA and Angelici CMLCD (2006). Transferability and use of microsatellite markers for the genetic analysis of the germplasm of some Arachis section species of the genus Arachis. Genet. Mol. Biol. 29: 516-524. http://dx.doi.org/10.1590/S1415-47572006000300021

Brazilian Ministry of Agriculture, Livestock, and Food Supply (2015). Exportação. Available at [http://www.agricultura. gov.br/animal/exportação]. Accessed November 22, 2015.

Carvalho GGP and Pires AJV (2008). Leguminosas tropicais em associação com pastagens. Archi. Zootec. 57: 103-113.

Claudino L, Gedouin M, Poccard-Chapuis R, Darnet LF, et al. (2013). Transformação nos território de produção bovina pelo desenvolvimento do setor agropecuário: estudo comparativo entre Brasil e Uruguai. Revista IDeAS 7: 8-42.

Coelho ASG. (2002). Software BOOD version 3.0. Laboratório Genética Vegetal, DBG/ICB: UFG.

Genetics and Molecular Research 15 (3): gmr.15038601 
Earl DA and vonHoldt BM (2012). STRUCTURE HARVESTER: a website and program for visualizing STRUCTURE output and implementing the Evanno method. Conserv. Genet. Resour. 4: 59-361. http://dx.doi.org/10.1007/s12686011-9548-7

Evanno G, Regnaut S and Goudet J (2005). Detecting the number of clusters of individuals using the software STRUCTURE: a simulation study. Mol. Ecol. 14: 2611-2620. http://dx.doi.org/10.1111/j.1365-294X.2005.02553.x

Friend SAD, Quandt SP, Tallury HT and Stalker KWH (2010). Species, genomes, and section relationships in the genus Arachis (Fabaceae): a molecular phylogeny. Plant. Syst. Evol. 290: 185-199. http://dx.doi.org/10.1007/s00606-010$\underline{0360-8}$

Gimenes MA, Hoshino AA, Barbosa AVG, Palmieri DA, et al. (2007). Characterization and transferability of microsatellite markers of the cultivated peanut (Arachis hypogaea). BMC Plant Biol. 7: 1-13. http://dx.doi.org/10.1186/1471-2229$\underline{7-9}$

Gimenes MA, Lopes CR, Galgaro ML, Valls JFM, et al. (2000). Genetic variation and phylogenetic relationships based on RAPD analysis in section Caulorrhizae, genus Arachis (Leguminosae). Euphytica 116: 187-195. http://dx.doi. org/10.1023/A:1004025619704

Hoisington D, Khairallah M and González-de-León D (1994). Laboratory protocols: CIMMYT applied molecular genetics laboratory, 2nd edn. CIMMYT, DF, México.

Hoshino AA, Bravo JP, Angelici CMLCD, Barbosa AVG, et al. (2006). Heterologous microsatellite primer pairs informative for the whole genus Arachis. Genet. Mol. Res. 29: 665-675.

Jones N, Ougham H, Thomas H and Pasakinskiene I (2009). Markers and mapping revisited: finding your gene. New Phytol. 183: 935-966. http://dx.doi.org/10.1111/j.1469-8137.2009.02933.x

Kalia RK, Rai MK, Kalia S, Singh R, et al. (2011). Microsatellite markers: an overview of the recent progress in plants. Euphytica 177: 309-334. http://dx.doi.org/10.1007/s10681-010-0286-9

Krapovickas AM and Gregory WC (1994). Taxonomía del género Arachis (Leguminosae). Bonplandia 1: 1-186.

Menezes APM, Assis GML, Mataveli M, Silva HSF, et al. (2012). Genetic divergence between genotypes of forage peanut in relation to agronomic and chemical traits. R. Bras. Zootec. 41: 1608-1617. http://dx.doi.org/10.1590/ $\underline{\text { S1516-35982012000700008 }}$

Monçato L (1995). Caracterização morfológica de germoplasma de espécies de Arachis, secção Caulorrhizae, pela análise multivariada. Master's thesis, Universidade Estadual Paulista, Botucatu.

Moretzsohn MC, Leoi L, Proite K, Guimarães PM, et al. (2005). A microsatellite based, gene-rich linkage map for the AA genome of Arachis (Fabaceae). Theor. Appl. Genet. 111: 1060-1071. http://dx.doi.org/10.1007/s00122-005-0028-x

Oliveira JC (2015). Estimativa da taxa de cruzamento de Arachis pintoi com marcadores microssatélites. Master's thesis, Universidade Federal do Acre, Rio Branco.

Palmieri DA, Hoshino AA, Bravo JP, Lopes CR, et al. (2002). Isolation and characterization of microsatellite loci from the forage species Arachis pintoi (Genus Arachis). Mol. Ecol. Notes 2: 551-553. http://dx.doi.org/10.1046/j.14718286.2002.00317.x

Palmieri DA, Bechara MD, Curi RA, Monteiro JP, et al. (2010). Genetic diversity analysis in the section Caulorrhizae (genus Arachis) using microsatellite markers. Genet. Mol. Biol. 33: 109-118. http://dx.doi.org/10.1590/S1415$\underline{47572010005000001}$

Pucciariello O, Ortiz AM, Fernández A and Lavia GI (2013). Análisis cromosómico del híbrido Arachis pintoi x A. repens (Leguminosae) mediante citogenética clásica y molecular. Bol. Soc. Argent. Bot. 48: 111-119.

Tessier C, David J, This P, Boursiquot JM, et al. (1999). Optimization of the choice of molecular markers for varietal identification in Vitis vinifera L. Theor. Appl. Genet. 98: 171-177. http://dx.doi.org/10.1007/s001220051054

Valentim JF and Andrade CMS (2009). Tendências e perspectivas da pecuária bovina na Amazônia brasileira. Amazônia: Cienc. Desenv. 4: 9-32.

Valentim JF and Andrade CMS (2015). Inovação tecnológica e intensificação dos sistemas de produção de bovinos de corte na Amazônia legal. Agrofoco 1: 18-19.

Valls VFM (2005). Recursos genéticos de Arachis: avanços no conhecimento botânico e a situação atual de conservação e uso. Agrociencia 9: 23-132.

Genetics and Molecular Research 15 (3): gmr.15038601 